\title{
A Comparison of the Solubility Products of Layered Me(II)-Al(III) Hydroxides Based on Sorption Studies with Ni(II), Zn(II), Co(II), Fe(II), and Mn(II)
}

\author{
Lasita Bhattacharya and Evert J. Elzinga * \\ Department of Earth \& Environmental Sciences, Rutgers University, Newark, NJ 07102, USA; \\ lasita.2007@gmail.com \\ * Correspondence: elzinga@rutgers.edu; Tel.: +1-973-353-5238
}

Received: 27 February 2018; Accepted: 4 April 2018; Published: 10 April 2018

\begin{abstract}
The precipitation of mixed metal-aluminum-layered double hydroxides (Me(II)-Al(III)-LDH)) may be an important control of the solubility of $\mathrm{Mn}$ (II), $\mathrm{Fe}(\mathrm{II}), \mathrm{Ni}(\mathrm{II}), \mathrm{Zn}(\mathrm{II})$, and $\mathrm{Co}(\mathrm{II})$ in soils, but assessment of this process is hindered by a lack of thermodynamic data. Here, we determined the solubility products (Ksp) of the $\mathrm{Me}(\mathrm{II})-\mathrm{Al}(\mathrm{III})-\mathrm{LDH}$ formed by these metals based on long-term $\mathrm{Me}(\mathrm{II})-\gamma \mathrm{Al}_{2} \mathrm{O}_{3}$ sorption studies complemented with X-ray absorption spectroscopy (XAS) measurements. The LDH phases had the chemical formula $\mathrm{Me}(\mathrm{II})_{2 / 3} \mathrm{Al}_{1 / 3}(\mathrm{OH})_{2} \mathrm{Cl}_{1 / 3}$. Solubility products were derived as $\mathrm{Ksp}=\left(\mathrm{Me}^{2+}\right)_{\mathrm{aq}}{ }^{2 / 3}\left(\mathrm{Al}^{3+}\right)_{\mathrm{aq}}{ }^{1 / 3}\left(\mathrm{OH}^{-}\right)_{\mathrm{aq}}{ }^{2}\left(\mathrm{Cl}^{-}\right)_{\mathrm{aq}}{ }^{1 / 3}$, where brackets represent aqueous activity values determined from the equilibrium solution chemistry of the sorption samples. The Ksps are metal-dependent, with values increasing by two orders of magnitude in the order $\mathrm{Ni}(\mathrm{II})$ $<\mathrm{Zn}(\mathrm{II})<\mathrm{Co}(\mathrm{II})<\mathrm{Fe}(\mathrm{II})<\mathrm{Mn}$ (II). Comparison to the solubility of $\beta-\mathrm{Me}(\mathrm{OH})_{2}$ suggests considerable thermodynamic preference of $\mathrm{Me}(\mathrm{II})-\mathrm{Al}(\mathrm{III})$ - $\mathrm{LDH}$ over $\beta-\mathrm{Me}(\mathrm{OH})_{2}$ in soil environments and reveals a linear relation between the log-transformed Ksp values of $\mathrm{Me}(\mathrm{II})-\mathrm{Al}(\mathrm{III})-\mathrm{LDH}$ and $\beta-\mathrm{Me}(\mathrm{OH})_{2}$. Solubility plots suggest that $\mathrm{Ni}(\mathrm{II})-, \mathrm{Zn}(\mathrm{II})-$, and $\mathrm{Co}(\mathrm{II})-\mathrm{Al}(\mathrm{III})-\mathrm{LDH}$ may form in metal-polluted soils. Fe(II)-Al(III)-LDH may occur in riparian soils undergoing reduction, but precipitation of $\mathrm{Mn}(\mathrm{II})-\mathrm{Al}(\mathrm{III})-\mathrm{LDH}$ appears unlikely as it requires $\left[\mathrm{Mn}^{2+}\right]_{\mathrm{aq}}$ much higher than commonly encountered in reducing soils. Additional thermodynamic and field studies are needed to further assess the importance of Me(II)-Al(III)-LDHs in soils and related geochemical systems.
\end{abstract}

Keywords: trace metals; layered double hydroxides; sorption; precipitation; solubility; aluminum

\section{Introduction}

In aqueous geochemical systems such as soils and sediments, sorption reactions at mineral-water interfaces significantly affect the mobility, speciation, and bioavailability of trace metals [1]. Iron and $\mathrm{Al}$ oxides and phyllosilicates are particularly important sorbents capable of metal retention through various mechanisms, including adsorption and precipitation reactions [1-3]. Recent studies have shown that the sorption of various divalent metals (Me(II)) from the first-row transition series (Ni(II), $\mathrm{Zn}(\mathrm{II}), \mathrm{Co}(\mathrm{II}), \mathrm{Fe}(\mathrm{II})$, and $\mathrm{Mn}(\mathrm{II}))$ onto Al-bearing mineral substrates may lead to the formation of $\mathrm{Me}(\mathrm{II})-\mathrm{Al}(\mathrm{III})-$ layered double hydroxides (LDHs) [4-31]. These phases consist of brucite-like $\left[\mathrm{Me}^{\mathrm{II}}(\mathrm{OH})_{2}\right]$ layers with partial isomorphous substitution of Me(II) by $\mathrm{Al}(\mathrm{III})$ derived from weathering of the mineral sorbent [25]. The substitution of $\mathrm{Al}(\mathrm{III})$ into the trioctahedral metal-hydroxide sheets generates a net positive layer charge, which is neutralized by interlayer anions such as nitrate, chloride, carbonate, and sulfate $[25,32]$. The resulting layered minerals have the general formula $\mathrm{Me}^{\mathrm{II}}{ }_{1-x} \mathrm{Al}^{\mathrm{III}}{ }_{x}$ $(\mathrm{OH})_{2}\left(\mathrm{~A}^{\mathrm{n}-}\right)_{\mathrm{x} / \mathrm{n}} \cdot \mathrm{nH}_{2} \mathrm{O}$, where $\mathrm{A}$ are the interlayer anions and $\mathrm{x}$ represents the extent of aluminum substitution, which varies from 0.2 to 0.35 [25]. These phases are part of the larger LDH family of 
minerals, which is formed by a range of metals including $\mathrm{Mg}, \mathrm{Mn}, \mathrm{Zn}, \mathrm{Co}, \mathrm{Ni}$, and $\mathrm{Fe}$ as the divalent metal species, and $\mathrm{Al}, \mathrm{Fe}, \mathrm{Cr}$, and $\mathrm{La}$ as the trivalent species [32-35].

The precipitation of $\mathrm{Me}(\mathrm{II})-\mathrm{Al}(\mathrm{III})-\mathrm{LDHs}$ has been observed during the sorption of divalent $\mathrm{Mn}$ (II), $\mathrm{Fe}(\mathrm{II}), \mathrm{Co}(\mathrm{II}), \mathrm{Ni}(\mathrm{II})$, and $\mathrm{Zn}(\mathrm{II})$ at circumneutral $\mathrm{pH}$ values in laboratory-based model systems using $\mathrm{Al}$ oxides and Al-containing clay minerals as adsorbents [4-31]. Kinetic studies have shown that the formation of these phases occurs on a time scale similar to adsorption reactions $[4,6,13,14,21,22,24,36]$, and thus is an effective mechanism for removing metal ions from solution. Recent work has identified $\mathrm{Ni}(\mathrm{II})-$ and $\mathrm{Zn}(\mathrm{II})-\mathrm{Al}(\mathrm{III})-\mathrm{LDH}$ phases in contaminated whole soils [36-45], suggesting that these minerals are an important control of the solubility and mobility of $\mathrm{Ni}$ (II) and $\mathrm{Zn}$ (II) pollutants in these systems.

The ability to model the occurrence and behavior of Me(II)-Al(III)-LDH phases in natural environments is limited by a lack of robust thermodynamic information, in particular solubility products (Ksp), which can be used to account for Me(II)-Al(III)-LDH precipitation in thermodynamic speciation calculations of aqueous geochemical systems. Table 1 presents an overview of studies reporting thermodynamic data for Me(II)-Al(III)-LDHs, with Ksp values derived from either solubility measurements [46,47], titrations [48], or solid-phase enthalpies measured with calorimetry $[40,49]$. Ksp estimates are available for the Me(II)-Al(III)-LDH phases formed by $\mathrm{Ni}(\mathrm{II}), \mathrm{Zn}(\mathrm{II}), \mathrm{Co}(\mathrm{II})$, and Fe(II) containing various charge-balancing anions (chloride, nitrate, sulfate, and carbonate). The values vary notably with Me(II) and anion type (Table 1), indicating that the thermodynamic stability of $\mathrm{Me}(\mathrm{II})-\mathrm{Al}(\mathrm{III})-\mathrm{LDH}$ is dependent on both the structural Me(II) cations and the interlayer anions building the structure [40,50]. However, part of the variability is due to factors other than compositional differences. This is well illustrated by the difference in Ksp values reported by Johnson and Glasser [46] and Allada et al. [49] for Ni(II)-Al(III)-LDH containing interlayer carbonate (i.e., $\left.\mathrm{Ni}(\mathrm{II})_{2 / 3} \mathrm{Al}(\mathrm{III})_{1 / 3}(\mathrm{OH})_{2}\left(\mathrm{CO}_{3}\right)_{1 / 6}\right)$. Despite similar composition, the Ksp values reported in the two studies differ by a factor of $\sim 10^{4}$ (Table 1), which, ceteris paribus, translates into a difference in $\mathrm{Ni}$ (II) solubility of approximately six orders of magnitude. This lack of consistency between currently available Ksp estimates highlights the need for additional work on the stability of Me(II)-Al(III)-LDH phases.

The aim of the current study was to determine and compare the solubility products of Me(II)$\mathrm{Al}(\mathrm{III})-\mathrm{LDH}$ precipitates formed by Ni(II), Zn(II), Co(II), Fe(II), and Mn(II). To this end, we adopted the approach of Zhu and Elzinga [27], who calculated the Ksp of Fe(II)-Al(III)-LDH based on long-term batch kinetic experiments tracking $\mathrm{Fe}(\mathrm{II})$ sorption in $\gamma-\mathrm{Al}_{2} \mathrm{O}_{3}$ suspensions over the course of three months with simultaneous monitoring of Fe(II) speciation by X-ray absorption spectroscopy. At $\mathrm{pH}$ values $\geq 7, \mathrm{Fe}$ (II) formed $\mathrm{Fe}(\mathrm{II})-\mathrm{Al}(\mathrm{III})$-LDH phases, for which Ksp values were calculated based on the solution chemistry of the equilibrated suspensions. Metal sorption in these experiments involves the gradual growth of $\mathrm{Me}(\mathrm{II})-\mathrm{Al}(\mathrm{III})-\mathrm{LDH}$ from dilute $\mathrm{Me}(\mathrm{II})$ solutions under well-controlled $\mathrm{pH}$ conditions, which can be tuned to control the saturation state and growth rate of the LDH phases [27]. We apply the method here to determine the Ksp values of $\mathrm{Me}_{2 / 3}^{\mathrm{II}} \mathrm{Al}_{1 / 3}^{\mathrm{III}}(\mathrm{OH})_{2} \mathrm{Cl}_{1 / 3}$ grown under similar conditions but containing different structural Me(II) cations (Fe(II), Mn(II), Co(II), Ni(II), or $\mathrm{Zn}(\mathrm{II})$ ), enabling systematic assessment of the influence of Me(II) type on the thermodynamic stability of these phases. 
Table 1. Overview of currently available thermodynamic studies of Me(II)-Al(III)-layered double hydroxides (LDHs).

\begin{tabular}{|c|c|c|c|c|c|}
\hline Source * & LDH Phase & Ksp Value ** & Synthesis Method & Ksp Measurement & Notes \\
\hline \multirow{4}{*}{ Boclair \& Braterman [48] } & $\mathrm{Mn}_{2 / 3} \mathrm{Al}_{1 / 3}(\mathrm{OH})_{2} \mathrm{Cl}_{1 / 3}$ & $1.12 \times 10^{-18}$ & \multirow{4}{*}{$\begin{array}{l}\text { Titration ( } 2 \mathrm{~h} \text { ) of } 2: 1 \text { mixed } \\
\text { Me(II):Al(III) solution to } \\
\text { alkaline } \mathrm{pH} \text { with base }\end{array}$} & \multirow{4}{*}{$\begin{array}{l}\text { Calculated from base consumption in } \\
\text { titration curve }\end{array}$} & \multirow{4}{*}{$\begin{array}{l}\text { Ksp values were not corrected for } \\
\text { effects of ionic strength and } \\
\text { aqueous complexation }\end{array}$} \\
\hline & $\mathrm{Co}_{2 / 3} \mathrm{Al}_{1 / 3}(\mathrm{OH})_{2} \mathrm{Cl}_{1 / 3}$ & $8.19 \times 10^{-20}$ & & & \\
\hline & $\mathrm{Ni}_{2 / 3} \mathrm{Al}_{1 / 3}(\mathrm{OH})_{2} \mathrm{Cl}_{1 / 3}$ & $5.45 \times 10^{-20}$ & & & \\
\hline & $\mathrm{Zn}_{2 / 3} \mathrm{Al}_{1 / 3}(\mathrm{OH})_{2} \mathrm{Cl}_{1 / 3}$ & $3.31 \times 10^{-20}$ & & & \\
\hline \multirow{3}{*}{ Johnson \& Glasser [46] } & $\mathrm{Co}_{2 / 3} \mathrm{Al}_{1 / 3}(\mathrm{OH})_{2}\left(\mathrm{CO}_{3}\right)_{1 / 6}$ & $4.23 \times 10^{-21}$ & \multirow{3}{*}{$\begin{array}{l}\text { Aging of alkaline } 2: 1 \\
\text { Me(II):Al(III) carbonate } \\
\text { solutions at } 70-80{ }^{\circ} \mathrm{C} \text { for } 1 \mathrm{wk}\end{array}$} & \multirow{3}{*}{$\begin{array}{l}\text { Calculated from solution chemistry of } \\
\text { LDH suspensions following } 147-411 \mathrm{~d} \\
\text { of equilibration. }\end{array}$} & \multirow{3}{*}{$\begin{array}{l}\text { Suspensions were prepared by } \\
\text { resuspending washed and dried } \\
\text { LDH material in carbonate solutions } \\
\text { following synthesis. }\end{array}$} \\
\hline & $\mathrm{Ni}_{2 / 3} \mathrm{Al}_{1 / 3}(\mathrm{OH})_{2}\left(\mathrm{CO}_{3}\right)_{1 / 6}$ & $4.75 \times 10^{-22}$ & & & \\
\hline & $\mathrm{Zn}_{2 / 3} \mathrm{Al}_{1 / 3}(\mathrm{OH})_{2}\left(\mathrm{CO}_{3}\right)_{1 / 6}$ & $8.58 \times 10^{-22}$ & & & \\
\hline \multirow[t]{2}{*}{ Peltier et al. [40] } & $\mathrm{Ni}_{2 / 3} \mathrm{Al}_{1 / 3}(\mathrm{OH})_{2}\left(\mathrm{CO}_{3}\right)_{1 / 6}$ & $1.58 \times 10^{-24}$ & \multirow{2}{*}{$\begin{array}{l}\text { Room-temperature controlled } \\
\text { hydrolysis method of } \\
\text { Taylor (1984) }\end{array}$} & \multirow{2}{*}{$\begin{array}{l}\text { Calculated from solid phase enthalpies } \\
\text { measured with calorimetry }\end{array}$} & \multirow{2}{*}{$\begin{array}{l}\text { LDH material was freeze-dried } \\
\text { before calorimetry measurements }\end{array}$} \\
\hline & $\mathrm{Ni}_{2 / 3} \mathrm{Al}_{1 / 3}(\mathrm{OH})_{2}\left(\mathrm{SO}_{4}\right)_{1 / 6}$ & $1.62 \times 10^{-25}$ & & & \\
\hline \multirow{2}{*}{ Allada et al. [49] } & $\mathrm{Ni}_{2 / 3} \mathrm{Al}_{1 / 3}(\mathrm{OH})_{2}\left(\mathrm{CO}_{3}\right)_{1 / 6}$ & $1.74 \times 10^{-26}$ & \multirow{2}{*}{$\begin{array}{l}\text { As in Johnson and } \\
\text { Glasser (2003) }\end{array}$} & \multirow{2}{*}{$\begin{array}{l}\text { Calculated from solid phase enthalpies } \\
\text { measured with calorimetry }\end{array}$} & \multirow{2}{*}{$\begin{array}{l}\text { LDH material was freeze-dried } \\
\text { before calorimetry measurements }\end{array}$} \\
\hline & $\mathrm{Zn}_{2 / 3} \mathrm{Al}_{1 / 3}(\mathrm{OH})_{2}\left(\mathrm{CO}_{3}\right)_{1 / 6}$ & $5.37 \times 10^{-25}$ & & & \\
\hline Regelink \& Temminghoff [47] & $\mathrm{Ni}_{2 / 3} \mathrm{Al}_{1 / 3}(\mathrm{OH})_{2}\left(\mathrm{CO}_{3}\right)_{1 / 6}$ & $8.58 \times 10^{-23}$ & $\begin{array}{l}\text { Aging of } 2: 1 \mathrm{Ni}(\mathrm{II}): \mathrm{Al}(\mathrm{III}) \\
\text { carbonate solutions at } \mathrm{pH} 8 \\
\text { for } 15-21 \mathrm{~d}\end{array}$ & $\begin{array}{l}\text { Calculated from the solution chemistry } \\
\text { of the LDH synthesis suspensions }\end{array}$ & $\begin{array}{l}\text { Additionally calculated Ksp without } \\
\text { accounting for anion activity } \\
\text { (equation } 3 \text { in text) }\end{array}$ \\
\hline Zhu \& Elzinga [27] & $\mathrm{Fe}_{2 / 3} \mathrm{Al}_{1 / 3}(\mathrm{OH})_{2}(\mathrm{Cl})_{1 / 3}$ & $9.43 \times 10^{-22 \#}$ & $\begin{array}{l}\mathrm{Fe}(\mathrm{II}) \text { sorption onto Al-oxide } \\
\text { at circumneutral } \mathrm{pH}\end{array}$ & $\begin{array}{l}\text { Calculated from solution chemistry of } \\
\text { equilibrated sorption samples }\end{array}$ & $\begin{array}{l}\text { Methods and calculations are } \\
\text { identical to those of the current study }\end{array}$ \\
\hline
\end{tabular}

* See reference list for full citation information. Most sources additionally report thermodynamic data for $\mathrm{LDH}$ phases other than the Me(II) $)_{2 / 3} \mathrm{Al}(\mathrm{III})_{1 / 3}(\mathrm{OH})_{2}\left(\mathrm{~A}^{\mathrm{n}-}\right)_{1 / 3 \mathrm{n}}$ materials of interest here. ${ }^{* *} \mathrm{Ksp}$ values apply to the expression $\mathrm{Ksp}=\left(\mathrm{Me}^{2+}\right)_{\mathrm{aq}}{ }^{2 / 3}\left(\mathrm{Al}^{3+}\right)_{\mathrm{aq}}{ }^{1 / 3}\left(\mathrm{~A}^{\mathrm{n}-}\right)_{\mathrm{aq}}{ }^{1 / 3 \mathrm{n}}\left(\mathrm{OH}^{-}\right)_{\mathrm{aq}}{ }^{2}$. \# Ksp was calculated assuming that either gibbsite $\left(\mathrm{Ksp}=9.43 \times 10^{-22}\right)$ or bayerite $\left(\mathrm{Ksp}=2.4 \times 10^{-21}\right)$ controlled $\left(\mathrm{Al}^{3+}\right)_{\mathrm{aq}}$ (see text). The solubility product of gibbsite used here was from the database of Visual MINTEQ 3.1 and is slightly different than that used by Zhu and Elzinga [27]. 


\section{Materials and Methods}

\subsection{Mineral Substrate}

The mineral sorbent used for the adsorption experiments was $\gamma-\mathrm{Al}_{2} \mathrm{O}_{3}$ purchased from Degussa. The substrate has a purity of $>99.6 \%$ as reported by the manufacturer, and a surface area of $100 \pm 15 \mathrm{~m}^{2} \mathrm{~g}^{-1}$ as measured by $\mathrm{N}_{2}$-BET. Powder X-ray diffraction (XRD) measurements of hydrated $\gamma-\mathrm{Al}_{2} \mathrm{O}_{3}$ samples used in our study are shown in Supplementary Materials, Figure S1, and confirm that the $\gamma-\mathrm{Al}_{2} \mathrm{O}_{3}$ substrate is metastable in aqueous solutions, where it transforms into a mixture of gibbsite and bayerite, consistent with previous work [51,52].

\subsection{Batch Sorption Experiments}

The sorption experiments were conducted inside a glovebox with a $95 \% \mathrm{~N}_{2}: 5 \% \mathrm{H}_{2}$ atmosphere to exclude $\mathrm{O}_{2(\mathrm{~g})}$ and $\mathrm{CO}_{2(\mathrm{~g})}$, in order to prevent redox reactions (of concern for $\mathrm{Fe}(\mathrm{II})$ and $\mathrm{Mn}(\mathrm{II})$ ) as well as any impacts of dissolved carbonate on metal sorption. The doubly deionized (DDI) water (resistivity $>18 \mathrm{M} \Omega \mathrm{cm}$ ) used for sample and reagent preparation was boiled to remove dissolved carbonate and oxygen, and then cooled inside the glovebox. The glovebox air was circulated continuously through a granular palladium catalyst using a fanbox (Coy Laboratories, Grass Lake, MI, USA) to eliminate trace $\mathrm{O}_{2(\mathrm{~g})}$.

The batch experiments involved kinetic studies monitoring the sorption of dissolved $\mathrm{Ni}(\mathrm{II})$, $\mathrm{Zn}(\mathrm{II}), \mathrm{Co}(\mathrm{II}), \mathrm{Fe}(\mathrm{II})$, and $\mathrm{Mn}(\mathrm{II})$ onto $\gamma-\mathrm{Al}_{2} \mathrm{O}_{3}$ over the course of weeks to months to ensure that sorption equilibrium was achieved. The $\gamma-\mathrm{Al}_{2} \mathrm{O}_{3}$ suspension density of the samples was $5.0 \mathrm{~g} \mathrm{~L}-1$, while ionic strength was set at $0.1 \mathrm{M}$ with $\mathrm{NaCl}$, and the metal concentration was $1.0 \mathrm{mM}$. For each metal, experiments were conducted at $\mathrm{pH}$ values of 3-4 in the near-neutral to alkaline range where the formation of $\mathrm{Me}(\mathrm{II})-\mathrm{Al}(\mathrm{III})-\mathrm{LDH}$ is favored [4-31]. Suspension $\mathrm{pH}$ values were stabilized by addition of $25 \mathrm{mM}$ of Good's buffers to the background electrolyte. The buffers used were CHES $(\mathrm{pKa}=9.30)$, EPPS ( $\mathrm{pKa}=8.00)$, HEPES ( $\mathrm{pKa}=7.50)$, and MES (pKa = 6.10) to cover the pH 6.5-9.5 range. Each experiment was run in triplicate to account for experimental variability.

The suspensions were hydrated for 3 days, and then spiked with appropriate aliquots of anoxic $0.1 \mathrm{M} \mathrm{MeCl}_{2}$ stocks $(\mathrm{Me}=\mathrm{Ni}, \mathrm{Zn}, \mathrm{Co}, \mathrm{Fe}$, or $\mathrm{Mn})$ to achieve an initial $\mathrm{Me}(\mathrm{II})$ concentration of $1.0 \mathrm{mM}$. For $\mathrm{Zn}(\mathrm{II})$, experiments were also conducted employing $\mathrm{Zn}$ (II) concentrations of $3 \mathrm{mM}$. The reaction vessels were capped and stored in sealed ziplock bags inside the glovebox for equilibration. Samples were taken regularly over the course of several months to track metal sorption. Sampling involved measurement of suspension $\mathrm{pH}$, followed by syringe filtration of a $10 \mathrm{~mL}$ subsample through a $0.22-\mu \mathrm{m}$ nitrocellulose membrane into a $15-\mathrm{mL}$ polyethylene tube containing $50 \mu \mathrm{L}$ of concentrated $\mathrm{HCl}$. The acidified filtrates were analyzed for the concentration of aqueous $\mathrm{Me}$ (II) using flame atom absorption spectrometry (FAAS). Sorption was calculated as the difference between the initial and remaining aqueous metal concentrations.

\subsection{XAS Analyses}

XAS measurements were performed to assess the precipitation of $\mathrm{Me}(\mathrm{II})-\mathrm{Al}(\mathrm{III})-\mathrm{LDH}$ phases in our experiments. After macroscopic equilibrium had been reached, reacted $\mathrm{Al}$ oxide solids were collected by filtering 30-mL aliquots taken from the batch kinetic reactors described in the previous section. The solids were sealed into XAS samples holders using Kapton tape and transported under anaerobic conditions to the synchrotron facility using procedures described in our previous work [26-28]. Extended X-ray absorption fine structure (EXAFS) measurements were conducted at beamline 12-BMB of the Advanced Photon Source at Argonne National Laboratory. The samples were scanned at the K-edge of Zn (9659 eV), Ni (8333 eV), Co (7709 eV), Fe (7112 eV), or Mn (6539 eV). The measurements were performed at room temperature and in fluorescence mode using a Canberra multielement detector. EXAFS data analysis was done with WinXAS 3.1 [53] in combination with ARTEMIS and Feff $[54,55]$, using procedures that are described in the Supplementary Materials. 
Besides the sorption samples, reference $\mathrm{Me}(\mathrm{II})-\mathrm{Al}(\mathrm{III})-\mathrm{LDH}$ phases were analyzed as well. For $\mathrm{Fe}(\mathrm{II})-\mathrm{Al}(\mathrm{III})-\mathrm{LDH}$, we used nikischerite, $\mathrm{NaFe}_{6}{ }_{6} \mathrm{Al}_{3}\left(\mathrm{SO}_{4}\right)_{2}(\mathrm{OH})_{18}\left(\mathrm{H}_{2} \mathrm{O}\right)_{12}$, a natural $\mathrm{Fe}(\mathrm{II})-\mathrm{Al}(\mathrm{III})-$ layered double hydroxide mineral with sulfate interlayer anions [56]. This sample was kindly provided by Tony Nikischer from the Excalibur Mineral Corporation, Charlottesville, VA, and has been described in our previous work [26-28]. Reference Me(II)-Al(III)-LDH phases for the four other metals were synthesized at room temperature according to the method of Taylor [32]. The Mn(II)-Al(III)-LDH was prepared in our laboratory at Rutgers-Newark, while the spectra of $\mathrm{Co}(\mathrm{II})-\mathrm{Al}(\mathrm{III})-\mathrm{LDH}, \mathrm{Ni}(\mathrm{II})-\mathrm{Al}(\mathrm{III})-\mathrm{LDH}$, and $\mathrm{Zn}(\mathrm{II})-\mathrm{Al}(\mathrm{III})-\mathrm{LDH}$ were kindly provided by Dr. Matt Siebecker from the University of Delaware and Dr. Wei Li from Nanjing University, and have been reported previously $[8,11,21,29,57]$.

\subsection{Thermodynamic Calculations}

The Ksp values of the Me(II)-Al(III)-LDH phases formed in the equilibrated sorption samples were estimated using the method described by Zhu and Elzinga [27]. This approach assumes that $\mathrm{Me}(\mathrm{II})-\mathrm{Al}(\mathrm{III})-\mathrm{LDH}$ phases control the $\mathrm{Me}(\mathrm{II})$ solubility in the samples, enabling calculation of Ksp from the aqueous Me(II) concentrations in the equilibrated suspensions [27]. The systems for which these calculations were performed were selected based on two criteria: (1) Me(II)-Al(III)-LDH had formed in the suspensions, as determined by the XAS analyses; and (2) the concentration of dissolved metal in the equilibrated solutions was sufficiently high for reliable analysis by FAAS. The calculations assume that the secondary $\mathrm{Me}(\mathrm{II})-\mathrm{Al}(\mathrm{III})-\mathrm{LDH}$ phases take on the ideal structural $\mathrm{Me}(\mathrm{II}): \mathrm{Al}(\mathrm{III})$ molar ratio of 2:1, so that their chemical formula is $\mathrm{Me}(\mathrm{II})_{2 / 3} \mathrm{Al}(\mathrm{III})_{1 / 3}(\mathrm{OH})_{2} \mathrm{Cl}_{1 / 3}$. The aqueous chemical equilibrium of these phases can be expressed as:

$$
\mathrm{Me}(\mathrm{II})_{2 / 3} \mathrm{Al}(\mathrm{III})_{1 / 3}(\mathrm{OH})_{2} \mathrm{Cl}_{1 / 3(\mathrm{~s})} \leftrightarrow \frac{2}{3} \mathrm{Me}^{2+}+\frac{1}{3} \mathrm{Al}^{3+}+2 \mathrm{OH}^{-}+\frac{1}{3} \mathrm{Cl}^{-}
$$

The corresponding solubility product, Ksp, is defined as:

$$
\mathrm{Ksp}=\left(\mathrm{Me}^{2+}\right)^{2 / 3} \times\left(\mathrm{Al}^{3+}\right)^{1 / 3} \times\left(\mathrm{OH}^{-}\right)^{2} \times\left(\mathrm{Cl}^{-}\right)^{1 / 3}
$$

where round brackets represent aqueous ion activities. In our experiments, the aqueous $\mathrm{OH}^{-}$activities were determined from the equilibrium $\mathrm{pH}$ values, while the equilibrium $\mathrm{Me}^{2+}{ }_{(\mathrm{aq})}$ concentrations were measured and the $\mathrm{Cl}^{-}$(aq) concentration was set by the background electrolyte. The concentration of dissolved $\mathrm{Al}^{3+}$, however, was too low for detection by our analytical techniques. Therefore, $\left(\mathrm{Al}^{3+}\right)_{\mathrm{aq}}$ was calculated by assuming that the solutions were in equilibrium with either gibbsite $\left(\alpha-\mathrm{Al}(\mathrm{OH})_{3}\right)$ or bayerite $\left(\beta-\mathrm{Al}(\mathrm{OH})_{3}\right)$, which are the $\mathrm{Al}$ oxide phases formed during transformation of the $\gamma-\mathrm{Al}_{2} \mathrm{O}_{3}$ sorbent in our systems as determined by XRD analyses of the Al oxide solids (Supplementary Materials, Figure S1). Activity coefficients for converting concentrations into activities were calculated with the Davies equation, while free aqueous metal activities were determined by accounting for the aqueous complexation of dissolved $\mathrm{Me}^{2+}$ with aqueous $\mathrm{Cl}^{-}$and $\mathrm{OH}^{-}$. The activity and aqueous complexation corrections were calculated with the program Visual MINTEQ version 3.1 [58] and the associated thermodynamic database.

In a second set of calculations, the solubility product was calculated according to:

$$
\mathrm{K}^{\prime} \mathrm{sp}=\left(\mathrm{Me}^{2+}\right)^{2 / 3} \times\left(\mathrm{Al}^{3+}\right)^{1 / 3} \times\left(\mathrm{OH}^{-}\right)^{2}
$$

This solubility product expression was proposed by Regelink and Temminghoff [47], who suggested that the formation of LDH phases is unaffected by the aqueous concentration of the counteranion (here $\mathrm{Cl}^{-}$) when the anion is present in excess relative to the concentrations of $\mathrm{Me}(\mathrm{II})$ and $\mathrm{Al}(\mathrm{III})$, as is the case in the current experiments. 


\section{Results and Discussion}

\subsection{Batch Kinetic Results}

The results of the batch kinetic studies are presented in Figure 1, which plots the aqueous metal concentrations as a function of time at the various $\mathrm{pH}$ values investigated for each metal. As perhaps expected, there are differences in sorption behavior between the metals, but some general similarities are observed as well. All systems exhibit biphasic metal sorption kinetics, where an initial fast sorption step within the first 1-2 days of reaction is followed by a slow reaction stage that continues until equilibrium is reached (Figure 1). Equilibration in these systems is slow, with reaction times on the order of weeks to months required to achieve sorption equilibrium (Figure 1). Suspension $\mathrm{pH}$ has a distinct impact on the kinetic sorption patterns, with both the extent and the rate of metal sorption increasing with $\mathrm{pH}$ (Figure 1). As an example, Fe(II) sorption equilibrium is reached after approximately 21, 64, and 104 days at $\mathrm{pH} 8.0,7.5$, and 7.0, respectively, with corresponding removal of $\sim 95 \%, 75 \%$, and $20 \%$ of added Fe(II) aq (Figure 1e). A similar pH effect is observed for the other metals. Of note are the distinct differences between the five metals with respect to the affinity of sorption at a given $\mathrm{pH}$ value. For example, at $\mathrm{pH} 7.0$, we observe removal (i.e., sorption) of $\sim 95 \%$ of added $\mathrm{Ni}$ (II), but of only $\sim 20 \%$ of added Fe(II) (Figure 1a,e). We interpret these differences in sorption affinity to reflect metal-dependent differences in the stability and solubility of the secondary $\mathrm{Me}(\mathrm{II})-\mathrm{Al}(\mathrm{III})$-LDH sorption products formed, as discussed below.
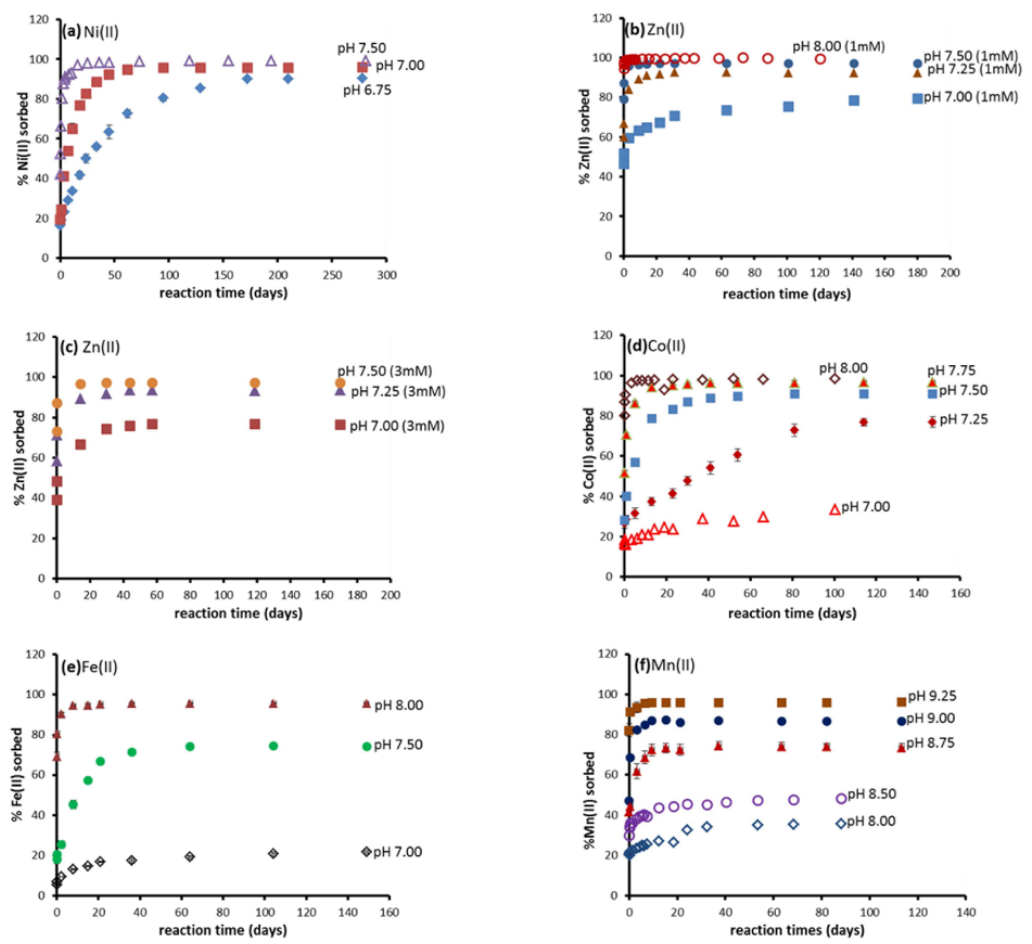

Figure 1. Results of the batch kinetic studies of $\mathrm{Me}(\mathrm{II})$ sorption onto $\gamma-\mathrm{Al}_{2} \mathrm{O}_{3}$ conducted with (a) $\mathrm{Ni}(\mathrm{II})$, $(\mathbf{b}, \mathbf{c}) \mathrm{Zn}(\mathrm{II}),(\mathbf{d}) \mathrm{Co}(\mathrm{II}),(\mathbf{e}) \mathrm{Fe}(\mathrm{II})$, and (f) $\mathrm{Mn}(\mathrm{II})$. All experiments were run in anoxic, $\mathrm{CO}_{2}$-free $\gamma-\mathrm{Al}_{2} \mathrm{O}_{3}$ suspensions with a density of $5 \mathrm{~g} \mathrm{~L}^{-1}$, a background electrolyte of $0.1 \mathrm{M} \mathrm{NaCl}$, and an initial aqueous $\mathrm{Me}(\mathrm{II})$ concentration of $1.0 \mathrm{mM}$. For $\mathrm{Zn}(\mathrm{II})$, an additional set of experiments was conducted with a $\mathrm{Zn}$ (II) concentration of $3.0 \mathrm{mM}$ (panel c). The data points represent the average of three replicate experiments; standard deviations are smaller than the data points in most cases. Closed and open symbols represent the data series used and discarded, respectively, for the calculation of the Ksp of $\mathrm{Me}(\mathrm{II})-\mathrm{Al}(\mathrm{III})-\mathrm{LDH}$. The $\mathrm{pH}$ values indicated along each data series are initial values, which are slightly higher than the final $\mathrm{pH}$ values. The solution chemistry of the equilibrated suspensions is summarized in Supplementary Materials, Table S2. 


\subsection{XAS Data}

The extended X-ray adsorption fine structure (EXAFS) data of select equilibrated sorption samples are presented in Figure 2, with Figure 2a showing the raw and fitted $k^{3}$-weighted $x$ spectra, and Figure $2 b$ the corresponding radial structure functions (RSFs) obtained from Fourier transformation of the raw $\chi$ data. For comparison, the EXAFS data of Me(II)-Al(III)-LDH reference compounds are included as well. The EXAFS data fitting results are summarized in Supplementary Materials, Table S1.

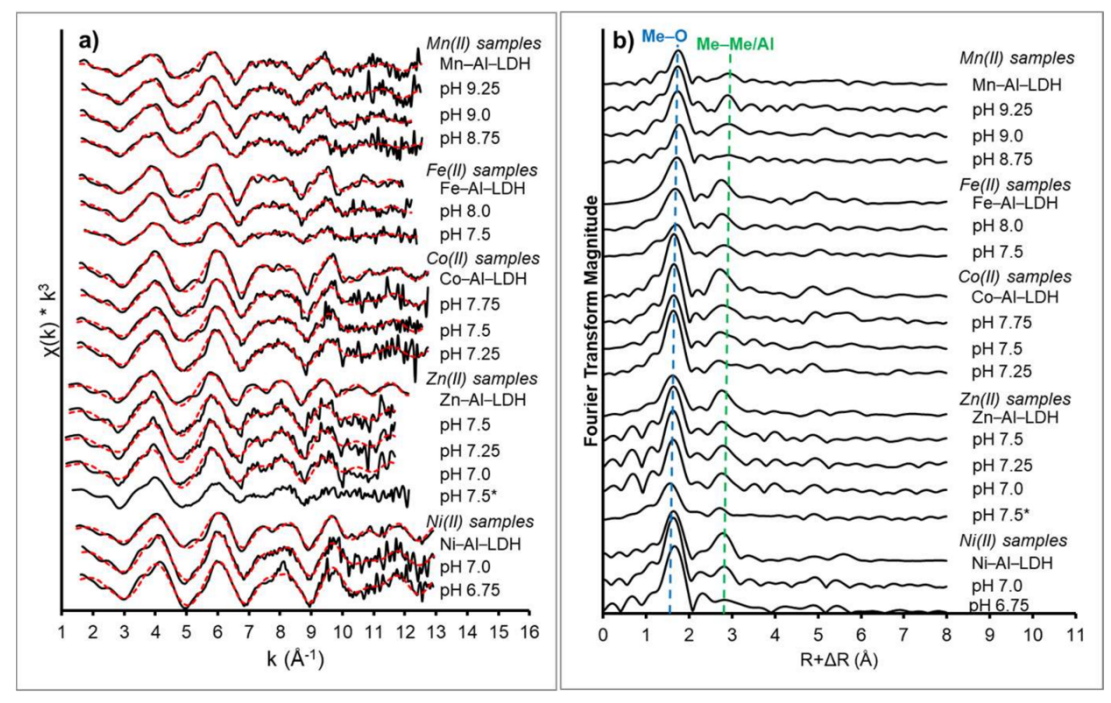

Figure 2. Me K-edge extended X-ray adsorption fine structure (EXAFS) data of sorption samples and $\mathrm{Me}(\mathrm{II})-\mathrm{Al}(\mathrm{III})-\mathrm{LDH}$ references: (a) $\mathrm{k}^{3}$-weighted $\chi$ spectra, and (b) corresponding radial structure functions (RSFs). Solid and dotted lines in panel a represent raw and fitted spectra, respectively, while the $\mathrm{y}$-axis tick marks in this panel are separated by a value of 25 . Dotted lines in panel $\mathbf{b}$ locate first-shell $\mathrm{O}$ and second-shell $\mathrm{Me} / \mathrm{Al}$ atomic neighbors. The data fit results are summarized in Supplementary Materials, Table S1. The $\mathrm{Zn}$ sorption samples were reacted at a $\mathrm{Zn}$ (II) concentration of $3.0 \mathrm{mM}$, except for the $\mathrm{pH} 7.5^{*}$ sample, which was reacted at $1.0 \mathrm{mM}$.

The RSFs shown in Figure $2 \mathrm{~b}$ all contain two peaks. The first is observed at $\mathrm{R}+\Delta \mathrm{R} \sim 1.8 \AA$ and represents the first-shell $\mathrm{O}$ ligands surrounding the central Me(II) cation. The second shells at $\mathrm{R}+\Delta \mathrm{R} \sim 2.9 \AA$ are due to the presence of metal neighbors in the coordination environment of the metal sorbates and indicate the formation of secondary metal precipitates. Fits of the first shells yield coordination numbers of 4.9-6.3 for the $\mathrm{O}$ atomic neighbors (Table S1), consistent with an octahedral arrangement of the first-shell $\mathrm{O}$ ligands around the central $\mathrm{Me}(\mathrm{II})$. The corresponding radial distances increase from 2.05 to $2.06 \AA$ for $\mathrm{Ni}$ (II) and Zn(II), to $2.08 \AA$ for $\mathrm{Co}(\mathrm{II}), 2.12 \AA$ for $\mathrm{Fe}(\mathrm{II})$, and $2.16 \AA$ for $\mathrm{Mn}(\mathrm{II})$. These values are consistent with the results of previous EXAFS studies of the sorption products formed by these divalent metals, for example, [4-12,14-18,20-22,27,30,31], and confirm the octahedral $\mathrm{Me}-\mathrm{O}$ coordination suggested by the fitted coordination numbers of the first shells [59]. The gradual decrease in Me-O separation with atomic number reflects the contraction in atomic radius for elements along periodic table rows, which is attributed to increased effective nuclear charge [60].

Fits of the second shells accounted for mixed contributions of second-neighbor $\mathrm{Me}(\mathrm{II})$ and $\mathrm{Al}(\mathrm{III})$ scattering. Although good fits were obtained when accounting for only second-neighbor Me(II) contributions, second-shell Al(III) was included as well. This was done because the raw $\mathrm{k}^{3}$-weighted $\chi$ spectra of the sorption samples strongly resemble the spectra of the $\mathrm{Me}(\mathrm{II})-\mathrm{Al}$ (III)-LDH references (Figure 2a). A key diagnostic feature is the truncated oscillation at $7-8 \AA^{-1}$, which is observed in all sorption spectra and has been identified as a fingerprint to distinguish $\mathrm{Me}$ (II)-Al(III)-LDH precipitates from $\alpha$ - and $\beta-\mathrm{Me}(\mathrm{II})(\mathrm{OH})_{2}$ and $\mathrm{Me}(\mathrm{II})$-phyllosilicate phases [11]. Because of the presence of Me(II)-Al(III)-LDH in these samples, the second shells were fitted with both $\mathrm{Me}(\mathrm{II})$ and $\mathrm{Al}(\mathrm{III})$ 
metal neighbors. The corresponding radial distances increase to $3.05 \AA$ for $\mathrm{Ni}(\mathrm{II})$, to $3.07-3.09 \AA$ for $\mathrm{Zn}(\mathrm{II})$ and $\mathrm{Co}(\mathrm{II})$, to $3.13 \AA$ for $\mathrm{Fe}(\mathrm{II})$, and $3.19 \AA$ for Mn(II) (Table S1). These values are consistent with those of previous EXAFS studies of the Me(II)-Al(III)-LDH phases formed by these metals [4-12,14-18,20-22,27,30,31], and demonstrate expansion of the LDH lattice with increasing ionic radius of the structural $\mathrm{Me}(\mathrm{II})$ cation. Overall, the results presented in Figure 2 confirm that the five metals studied here precipitate as secondary $\mathrm{Me}(\mathrm{II})-\mathrm{Al}(\mathrm{III})-\mathrm{LDH}$ phases in our sorption systems.

Comparison of the XAS spectra of the sorption samples to those of the reference $\mathrm{Me}(\mathrm{II})-\mathrm{Al}(\mathrm{III})-\mathrm{LDH}$ compounds shows that the features diagnostic of LDH precipitates are dampened in the sorption spectra (Figure 2). We attribute this to the presence of adsorbed metal species forming alongside $\mathrm{Me}(\mathrm{II})-\mathrm{Al}(\mathrm{III})-\mathrm{LDH}$ through interactions with the Al oxide surface. Since EXAFS characterizes the average Me(II) coordination in these samples, such monomeric Me(II) surface species "dilute" the signal of Me(II)-Al(III)-LDH and reduce the intensity of second-shell metal backscattering $[13,14]$. Support for this interpretation is provided by the results of the $\mathrm{Zn}$ (II) systems, where there is a distinct difference in $\mathrm{Zn}-\mathrm{O}$ coordination between adsorbed and precipitated $\mathrm{Zn}(\mathrm{II}): \mathrm{Zn}(\mathrm{II})$ adsorbs at the $\mathrm{Al}$ oxide surface as a tetrahedral inner-sphere complex, while Zn(II) in $\mathrm{Zn}$ (II)-Al(III)-LDH is octahedral [22]. These two Zn species can be distinguished by EXAFS due to the difference in radial distance of first shell $\mathrm{Zn}-\mathrm{O}$, which is distinctly shorter for tetrahedral $\left(\mathrm{R}_{\mathrm{Zn}-\mathrm{O}} \approx 1.95 \AA\right.$ ) than for octahedral Zn(II) $\left(\mathrm{R}_{\mathrm{Zn}-\mathrm{O}} \approx 2.07 \AA\right.$ ) [59]. At pH 7.5, Zn(II)-Al(III)-LDH phases form in both the $1 \mathrm{mM}$ and $3 \mathrm{mM}$ samples, as evidenced by the presence of second-shell $\mathrm{Zn}$ and $\mathrm{Al}$ backscatterers (Figure $2 b$, Table S1). However, the first-shell $\mathrm{Zn}-\mathrm{O}$ radial distance of $2.01 \AA$ found for the $1 \mathrm{mM}$ sample (Table S1) is intermediate between tetrahedral and octahedral coordination, indicating the presence of a substantial population of monomeric $\mathrm{Zn}$ (II) complexes in addition to $\mathrm{Zn}(\mathrm{II})-\mathrm{Al}(\mathrm{III})-\mathrm{LDH}$, as also observed by Li et al. [22]. The $3 \mathrm{mM}$ samples, in contrast, are dominated by $\mathrm{Zn}(\mathrm{II})-\mathrm{Al}(\mathrm{III})-\mathrm{LDH}$, as evidenced by the $\mathrm{Zn}-\mathrm{O}$ distance of $2.06 \AA$ (Table S1) indicative of octahedral $\mathrm{Zn}$ (II). The substantial presence of monomeric $\mathrm{Zn}$ (II) surface species in the $1 \mathrm{mM}$ samples does not affect the Ksp estimate of $\mathrm{Zn}(\mathrm{II})-\mathrm{Al}(\mathrm{III})-\mathrm{LDH}$, as will be shown in the next section.

\subsection{Ksp Estimates}

The average solubility products calculated from the macroscopic sorption data of the five metals are presented in Table 2; the concentrations and activities of aqueous $\mathrm{Me}^{2+}, \mathrm{OH}^{-}$, and $\mathrm{Al}^{3+}$ in the equilibrated sorption samples used to derive these values are summarized in Supplementary Materials, Table S2. Table 2 reports both the Ksp and K'sp values (calculated with and without account of $\mathrm{Cl}^{-}$ anion activity using Equations (2) and (3), respectively), and assuming either gibbsite or bayerite as the $\mathrm{Al}$ oxide mineral phase controlling $\mathrm{Al}$ solubility. The Ksps of the $\beta-\mathrm{Me}(\mathrm{II})(\mathrm{OH})_{2}$ phases formed by the five metals are provided as well.

Table 2. Summary of the Ksp values obtained in this study.

\begin{tabular}{|c|c|c|c|c|c|}
\hline \multirow{3}{*}{$\mathrm{Me}(\mathrm{II})$} & \multicolumn{4}{|c|}{ Me(II)-Al(III)-LDH } & \multirow{3}{*}{$\frac{\beta-\mathrm{Me}(\mathrm{OH})_{2}}{\mathrm{Ksp}^{* * *}}$} \\
\hline & \multicolumn{2}{|c|}{ With Anion Activitiy * } & \multicolumn{2}{|c|}{ Without Anion Activity * } & \\
\hline & Ksp (gibbsite) ** & Ksp (bayerite) ** & K'sp (gibbsite) ** & K'sp (bayerite) ** & \\
\hline $\mathrm{Ni}(\mathrm{II})$ & $8.43( \pm 0.1) \times 10^{-23}$ & $2.16( \pm 0.02) \times 10^{-22}$ & $2.00( \pm 0.02) \times 10^{-22}$ & $5.11( \pm 0.04) \times 10^{-22}$ & $10^{-17.21}$ \\
\hline $\mathrm{Zn}(\mathrm{II})$ & $1.89( \pm 0.05) \times 10^{-22}$ & $4.81( \pm 0.12) \times 10^{-22}$ & $4.46( \pm 0.11) \times 10^{-22}$ & $1.14( \pm 0.03) \times 10^{-21}$ & $10^{-16.25}$ \\
\hline $\mathrm{Co}(\mathrm{II})$ & $3.58( \pm 0.13) \times 10^{-22}$ & $9.13( \pm 0.34) \times 10^{-22}$ & $8.48( \pm 0.30) \times 10^{-22}$ & $2.16( \pm 0.08) \times 10^{-21}$ & $10^{-15.71}$ \\
\hline $\mathrm{Fe}(\mathrm{II})$ & $7.55( \pm 0.06) \times 10^{-22}$ & $1.93( \pm 0.02) \times 10^{-21}$ & $1.79( \pm 0.01) \times 10^{-21}$ & $4.55( \pm 0.04) \times 10^{-21}$ & $10^{-15.11}$ \\
\hline $\mathrm{Mn}(\mathrm{II})$ & $1.27( \pm 0.02) \times 10^{-20}$ & $3.23( \pm 0.04) \times 10^{-20}$ & $3.00( \pm 0.04) \times 10^{-20}$ & $7.65( \pm 0.10) \times 10^{-20}$ & $10^{-12.81}$ \\
\hline
\end{tabular}

${ }^{*}$ Ksp (accounting for anion activity) and $\mathrm{K}^{\prime} \mathrm{sp}$ (ignoring anion activity) values were calculated based on Equations (2) and (3), respectively. Uncertainties are standard deviations of the values obtained at different $\mathrm{pH}$ for a given metal. A summary of the aqueous solution chemical data used in the calculations is provided in Supplementary Materials, Table S2. ${ }^{* *} \mathrm{Ksp}$ and $\mathrm{K}$ 'sp values were calculated assuming control of $\left(\mathrm{Al}^{3+}\right)_{\mathrm{aq}}$ by either gibbsite or bayerite. ${ }^{* * *} \mathrm{Ksp}$ values of $\beta-\mathrm{Me}(\mathrm{OH})_{2}$ from the thermodynamic database of Visual MINTEQ 3.1. The values apply to the equilibrium $\beta-\mathrm{Me}(\mathrm{OH})_{2(\mathrm{~s})} \leftrightarrow \mathrm{Me}^{2+}(\mathrm{aq})+2 \mathrm{OH}^{-}$(aq) 
Comparisons of the average Ksp values in Table 2 show that $\mathrm{Ni}(\mathrm{II})-\mathrm{Al}(\mathrm{III})-\mathrm{LDH}$ has the lowest solubility $\left(\mathrm{Ksp}=8.43( \pm 0.1) \times 10^{-23}\right.$ and $\mathrm{K}^{\prime} \mathrm{sp}=2.16( \pm 0.02) \times 10^{-22}$, assuming control of $\left(\mathrm{Al}^{3+}\right)_{\text {aq }}$ by gibbsite), while $\mathrm{Mn}(\mathrm{II})-\mathrm{Al}(\mathrm{III})-\mathrm{LDH}$ is the most soluble $\left(\mathrm{Ksp}=1.27( \pm 0.02) \times 10^{-20}\right.$ and $\mathrm{K}^{\prime} \mathrm{sp}=3.23$ $\left.( \pm 0.04) \times 10^{-20}\right)$. This range of Ksp values translates into approximately three orders of magnitude of difference in dissolved $\mathrm{Ni}(\mathrm{II})$ versus dissolved $\mathrm{Mn}(\mathrm{II})$ at a given $\mathrm{pH}$, and thus indicates substantial variation in the stability and thermodynamic favorability of Me(II)-Al(III)-LDH precipitation among the five metals. This is consistent with the macroscopic data, where notable differences in the extent of metal sorption are observed at a given $\mathrm{pH}$ value (Figure 1). We further note that the Ksp values calculated for the $1 \mathrm{mM}$ and $3 \mathrm{mM} \mathrm{Zn}$ (II) experiments are the same within uncertainty (see Supplementary Materials, Table S2). This indicates that there is no significant difference in the solubility of the $\mathrm{Zn}(\mathrm{II})-\mathrm{Al}(\mathrm{III})-\mathrm{LDH}$ phases formed in the high- and low-concentration systems.

The average solubility (Ksp) values are accompanied by uncertainties that were calculated from the Ksp estimates obtained at the different $\mathrm{pH}$ values studied for each metal (Table 2). These uncertainties amount to approximately $0.6 \%$ of the average for Fe(II) to $3.7 \%$ for $\mathrm{Co}(\mathrm{II})$, while those of $\mathrm{Zn}$ (II), $\mathrm{Mn}$ (II), and $\mathrm{Ni}(\mathrm{II})$ are $\sim 2.5 \%, 1.5 \%$, and $1.0 \%$, respectively. These values are within the range of uncertainty of the aqueous metal concentrations, which was $\sim 5 \%$ as determined by the results of the replicate samples run for each experiment and from quality control samples measured during AA analysis. This suggests that random experimental error is the main source of uncertainty in these Ksp values, and that any systematic error resulting from the $\mathrm{pH}$ dependence of (i) the mineralogical transformation of the $\gamma-\mathrm{Al}_{2} \mathrm{O}_{3}$ sorbent (Figure S1; which may affect $\mathrm{Al}$ solubility); and (ii) the rate of $\mathrm{LDH}$ precipitation (Figure 1; which may lead to $\mathrm{pH}$-dependent differences in the particle size and composition, and therefore solubility, of the LDH phases) is negligible. Of further note is that the uncertainties in Ksp for individual metals are much smaller than the differences in Ksp between the metals (Table 1), indicating that our results provide a robust comparison of the solubility of the five $\mathrm{Me}(\mathrm{II})-\mathrm{Al}(\mathrm{III})-\mathrm{LDH}$ types.

Further inspection of the data reported in Table 2 indicates that the Ksp values of Me(II)$\mathrm{Al}(\mathrm{III})-\mathrm{LDH}$ and $\beta-\mathrm{Me}(\mathrm{II})(\mathrm{OH})_{2}$ are correlated. Figure 3 plots the log-transformed Ksp values of $\mathrm{Me}(\mathrm{II})-\mathrm{Al}(\mathrm{III})-\mathrm{LDH}$ (calculated with Equation (2), assuming that $\left(\mathrm{Al}^{3+}\right)_{\mathrm{aq}}$ is controlled by gibbsite) against those of $\beta-\mathrm{Me}(\mathrm{II})(\mathrm{OH})_{2}$, and reveals a linear relation between the two variables. This is noteworthy in that it demonstrates that the solubility of the Me(II)-Al(III)-LDH phases is not affected in a major way by the size mismatch between the $\mathrm{Al}(\mathrm{III})$ and $\mathrm{Me}(\mathrm{II})$ cations. The ionic radius of octahedral $\mathrm{Al}^{3+}\left(0.535 \AA\right.$ [59]) is distinctly smaller than those of the $\mathrm{Me}^{2+}$ cations it replaces in $\beta-\mathrm{Me}(\mathrm{II})(\mathrm{OH})_{2}$ to form Me(II)-Al(III)-LDH (0.69-0.78 $\AA$ [59]). This likely imposes an energetic "penalty" that partially offsets the overall higher stability of $\mathrm{Me}(\mathrm{II})-\mathrm{Al}(\mathrm{III})-\mathrm{LDH}$ relative to $\beta-\mathrm{Me}(\mathrm{II})(\mathrm{OH})_{2}$. The magnitude of this effect is expected to increase with an increase in the size of $\mathrm{Me}$ (II) relative to that of $\mathrm{Al}(\mathrm{III})$ [49], and this would yield a nonlinear relation between the Ksp values of $\beta-\mathrm{Me}(\mathrm{II}) \mathrm{OH})_{2}$ and $\mathrm{Me}(\mathrm{II})-\mathrm{Al}(\mathrm{III})-\mathrm{LDH}$ if the effect were pronounced. Since we instead observe a linear relation between the two variables (Figure 2), we conclude that the effect is small relative to the differences in stability of the $\beta-\mathrm{Me}(\mathrm{II})(\mathrm{OH})_{2}$ basis structures. As a result, the solubility of the $\mathrm{Me}(\mathrm{II})-\mathrm{Al}(\mathrm{III})-\mathrm{LDH}$ phases can be predicted in a rather robust fashion from the Ksp values of the corresponding $\mathrm{Me}(\mathrm{OH})_{2}$ phases. It is likely that the Ksps of $\mathrm{Me}(\mathrm{II})-\mathrm{Al}(\mathrm{III})-\mathrm{LDH}$ phases having interlayer anions other than $\mathrm{Cl}^{-}$are correlated to the Ksp of $\beta-\mathrm{Me}(\mathrm{II})(\mathrm{OH})_{2}$ as well, and that similar correlations apply to LDH phases with different layer compositions than the $\mathrm{Me}(\mathrm{II})_{0.67} \mathrm{Al}(\mathrm{III})_{0.33}(\mathrm{OH})_{2}$ phases studied here. Our results therefore suggest that the thermodynamic properties of $\beta-\mathrm{Me}(\mathrm{OH})_{2}$ provide a useful starting point for predicting thermodynamic trends within the diverse LDH mineral family.

A final comparison we make for the Ksp data presented in Table 2 is to those of earlier studies (summarized in Table 1). Our results are in good agreement with the results of Zhu and Elzinga [27], who report a Ksp estimate for $\mathrm{Fe}(\mathrm{II})_{2 / 3} \mathrm{Al}(\mathrm{III})_{1 / 3}(\mathrm{OH})_{2} \mathrm{Cl}_{1 / 3}$ determined from very similar experiments to those conducted here. The value agrees to within $30 \%$ of the Ksp estimate obtained from the current experiments (Tables 1 and 2). We attribute the slight difference to the different $\gamma-\mathrm{Al}_{2} \mathrm{O}_{3}$ substrates used in the two studies. Comparisons to the other studies reported in Table 1 are less favorable. 
Our Ksp values are within an order of magnitude of those measured by Johnson and Glasser [46] and Regelink and Temminghoff [47], while the differences with the values of Peltier et al. [40] and Boclair and Braterman [48] are larger, amounting to approximately two orders of magnitude (Table 1). There are many factors that may contribute to these discrepancies, including differences in sample preparation, LDH composition, and the method of Ksp measurement (see summary in Table 1). Boclair and Braterman [48] characterized similar materials as used here, represented by $\mathrm{Me}(\mathrm{II})_{2 / 3} \mathrm{Al}(\mathrm{III})_{1 / 3}(\mathrm{OH})_{2} \mathrm{Cl}_{1 / 3}$, but report Ksp values much larger than ours (Tables 1 and 2). A likely cause is that their values were calculated based on total metal concentrations not corrected for activity or solution complexation, as was done here. In addition, their synthesis method involved LDH growth over the course of just a few hours (Table 1), which is much shorter than the time frame of Me(II)-Al(III)-LDH growth in our experiments (Figure 1). The LDH phases of Boclair and Braterman [48] therefore likely had a lower crystallinity, and thus a higher solubility, than those characterized here, consistent with the observed differences in Ksp (Tables 1 and 2).

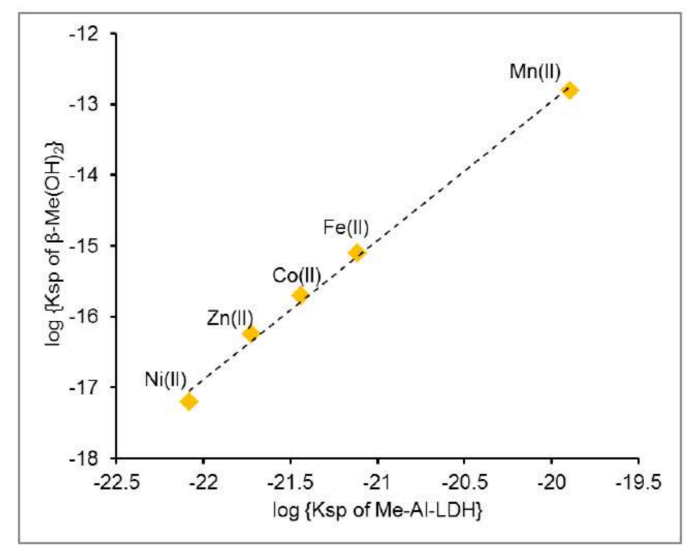

Figure 3. Correlation between the log-transformed Ksp values of $\mathrm{Me}(\mathrm{II})_{2 / 3} \mathrm{Al}_{1 / 3}(\mathrm{OH})_{2} \mathrm{Cl}_{1 / 3}$ and $\beta-\mathrm{Me}(\mathrm{OH})_{2}$. The Ksp values of $\mathrm{Me}(\mathrm{II})-\mathrm{Al}(\mathrm{III})-\mathrm{LDH}$ were calculated according to Equation (2) of the text, assuming gibbsite as the $\mathrm{Al}$ oxide phase regulating $\left(\mathrm{Al}^{3+}\right)_{\text {aq }}$ (see Table 2$)$. The Ksp values of $\beta-\mathrm{Me}(\mathrm{OH})_{2}$ apply to the equilibrium $\beta-\mathrm{Me}(\mathrm{OH})_{2(\mathrm{~s})} \leftrightarrow \mathrm{Me}^{2+}{ }_{(\mathrm{aq})}+2 \mathrm{OH}^{-}{ }_{\text {(aq) }}$ and were taken from the Visual MINTEQ 3.1 database.

Comparison of our results to those of Peltier et al. [40], Johnson and Glasser [46], and Regelink and Temminghoff [47] is complicated by the fact that none of these earlier studies used $\mathrm{Cl}^{-}$as the charge-balancing anion (Table 1). This makes direct comparison to our results difficult, because counteranion type affects the stability (and therefore the Ksp value) of Me(II)-Al(III)-LDH [40,50], and determines the stoichiometry of anion activity in the Ksp expression (Table 1). Comparisons are additionally complicated by considerable differences in sample synthesis and pretreatment (Table 1), which may affect Ksp through impacts on particle crystallinity, composition, and morphology; and by differences in measurement methodology, which may introduce systematic error. Delineating these effects will require studies that systematically address the impacts of layer and interlayer composition on LDH stability, ideally with a complementary combination of solubility and calorimetry measurements. The sorption method used here may be a useful tool in future thermodynamic studies of LDH minerals, as it can be readily adapted for the systematic assessment of the influence of growth rate, interlayer composition, and sorbent type on LDH stability.

\subsection{Me(II)-Al(III)-LDH Stability Relative to That of Other Me(II) Phases}

Figure 4 provides a comparison of the thermodynamic stability of Me(II)-Al(III)-LDH to that that of $\beta-\mathrm{Me}(\mathrm{II})(\mathrm{OH})_{2}$ and $\mathrm{Me}(\mathrm{II}) \mathrm{CO}_{3}$ at $\mathrm{pH}$ 6.0-8.5 for the five metals studied. Plotted are the $\mathrm{Me}(\mathrm{II})$ concentrations of solutions equilibrated with either $\mathrm{Me}(\mathrm{II})-\mathrm{Al}(\mathrm{III})-\mathrm{LDH}, \beta-\mathrm{Me}(\mathrm{II})(\mathrm{OH})_{2}$, or $\mathrm{Me}(\mathrm{II}) \mathrm{CO}_{3}$, 
as calculated with Visual MINTEQ 3.1 for $0.01 \mathrm{M} \mathrm{CaCl}_{2}$ electrolytes exposed to atmospheric $P_{\mathrm{CO} 2}$ $\left(10^{-3.5} \mathrm{~atm}\right)$ and in equilibrium with gibbsite. The solubility of Me(II)-Al(III)-LDH was calculated using both Equation (2) (black solid lines in Figure 4, denoted as Me-Al-LDH [1] in the figure legend), which accounts for the $\mathrm{Cl}^{-}$activity in the Ksp expression, and Equation (3) (dotted lines, denoted as $\mathrm{Me}-\mathrm{Al}-\mathrm{LDH}$ [2]), where $\mathrm{Cl}^{-}$is ignored.

The overall solubility trends of the Me(II) phases plotted in Figure 4 are similar. Dissolved Me(II) concentrations decrease with $\mathrm{pH}$, demonstrating the importance of this variable in regulating the precipitation of these Me(II) minerals. The Me(II)-Al(III)-LDH phases are less soluble (i.e., more stable) than their $\beta-\mathrm{Me}(\mathrm{II})(\mathrm{OH})_{2}$ counterparts by approximately two orders of magnitude (Figure 4), indicating considerable thermodynamic favorability of $\mathrm{Me}(\mathrm{II})-\mathrm{Al}(\mathrm{III})-\mathrm{LDH}$ over $\beta-\mathrm{Me}(\mathrm{II})(\mathrm{OH})_{2(\mathrm{~s})}$ in geochemical systems where $\mathrm{Al}$ oxides are present. There is a slight difference in $\mathrm{Me}(\mathrm{II})-\mathrm{Al}(\mathrm{III})$-LDH solubility calculated by Equations (2) and (3), with equilibrium Me(II) concentrations based on Equation (2) (taking into account $\mathrm{Cl}^{-}$activity) 2-3 times higher than those computed with Equation (3) (Figure 4). The stability of $\mathrm{Me}(\mathrm{II})-\mathrm{Al}(\mathrm{III})-\mathrm{LDH}$ relative to $\mathrm{MeCO}_{3(\mathrm{~s})}$ is metal dependent. The carbonate phases of $\mathrm{Ni}(\mathrm{II})$ and $\mathrm{Zn}$ (II) are more soluble (i.e., less stable) than the $\mathrm{LDH}$ phases across the $\mathrm{pH}$ range considered (Figure 4). The opposite is true for $\mathrm{Mn}(\mathrm{II})$, while for $\mathrm{Co}(\mathrm{II})$ and $\mathrm{Fe}(\mathrm{II})$, the relative stabilities of the carbonate and $\mathrm{LDH}$ phases reverse at $\mathrm{pH}$ 7.0-8.0 (Figure 4). These trends reflect decreasing stability of Me-Al-LDH in the order $\mathrm{Zn}>\mathrm{Ni}>\mathrm{Co}>\mathrm{Fe}>\mathrm{Mn}$ (Figure 3; Table 2), combined with increasing stability of $\mathrm{MeCO}_{3(\mathrm{~s})}$ in the same order.

Inspection of the Me(II) solubilities plotted in Figure 4 shows that Me(II)-Al(III)-LDH phases maintain $\mathrm{Me}(\mathrm{II})_{\mathrm{aq}}$ concentrations of $\sim 10^{-2}-10^{-6} \mathrm{M}$, depending on $\mathrm{pH}$. Concentrations of this level for trace metals $\mathrm{Ni}(\mathrm{II}), \mathrm{Zn}(\mathrm{II})$, and $\mathrm{Co}(\mathrm{II})$ in soil and sediment pore waters would reflect polluted environments subject to considerable external input of metal contaminants. Indeed, the studies which have identified $\mathrm{Ni}(\mathrm{II})-$ and $\mathrm{Zn}(\mathrm{II})-\mathrm{Al}(\mathrm{III})-\mathrm{LDH}$ minerals in field soils all dealt with contaminated samples enriched in $\mathrm{Ni}(\mathrm{II})$ and $\mathrm{Zn}$ (II) [36-45]. For Mn(II) and particularly Fe(II), aqueous concentrations in the sub-mM and $\mathrm{mM}$ range are common in suboxic soils undergoing active reduction of $\mathrm{Mn}$ and $\mathrm{Fe}$ oxides, as occurs in, for example, river floodplains and rice paddies [61-65]. Typical $\mathrm{pH}$ values in these reducing environments are in the near-neutral range [65-67]. These conditions may favor the formation of $\mathrm{Fe}(\mathrm{II})-\mathrm{Al}(\mathrm{III})-\mathrm{LDH}$, based on the thermodynamic information acquired here (Figure 4d). Formation of $\mathrm{Mn}(\mathrm{II})-\mathrm{Al}(\mathrm{III})-\mathrm{LDH}$, however, appears less feasible in view of the high $\mathrm{Mn}(\mathrm{II})$ concentrations required to induce precipitation at near-neutral $\mathrm{pH}\left(>10^{-2} \mathrm{M}\right.$; Figure $\left.4 \mathrm{e}\right)$.

The thermodynamic calculations presented in Figure 4 suggest the potential importance of metal carbonates in regulating dissolved levels of $\mathrm{Fe}(\mathrm{II}), \mathrm{Mn}(\mathrm{II})$, and $\mathrm{Co}(\mathrm{II})$, especially when considering that $P_{\mathrm{CO} 2}$ in soil air often exceeds the atmospheric levels applied in the solubility calculations. We note, however, that factors other than thermodynamic favorability need to be considered as well in predicting $\mathrm{Me}(\mathrm{II})$ precipitation in natural systems. Humic acids and phosphate anions may inhibit the formation of pure $\mathrm{MeCO}_{3(\mathrm{~s})}$ by poisoning mineral growth or by mediating alternative complexation and precipitation reactions, for example, in [65,68-71]. Since these compounds are common in soils and sediments, they may hinder the formation of $\mathrm{MeCO}_{3(\mathrm{~s})}$ in these systems even when substantial supersaturation occurs [64,65]. In contrast, LDH phases have been shown to form in whole soils [36-45] as well in model systems containing humic substances and arsenate (the chemical analogue of phosphate) [28,72-75]. This suggests that LDH formation is not particularly susceptible to interference by foreign solutes. A further consideration is that the Me(II)-Al(III)-LDH phases characterized in this study contain $\mathrm{Cl}^{-}$as the interlayer anion. Peltier et al. [40] have demonstrated that the identity of the counteranion has a substantial impact on the solubility of $\mathrm{Me}$ (II)-Al(III)-LDH, with carbonate and silicate anions providing the most stability (Table 1). Application of the Ksp values of the chloride-interlayered LDH phases characterized here may therefore under-predict the thermodynamic favorability of LDHs formation in near-surface environments such as soils where carbonate and silicate are abundant. Assessment of the formation and stability of $\mathrm{Me}(\mathrm{II})-\mathrm{Al}(\mathrm{III})-\mathrm{LDH}$ phases in natural systems will require further thermodynamic as well as field-based studies. 

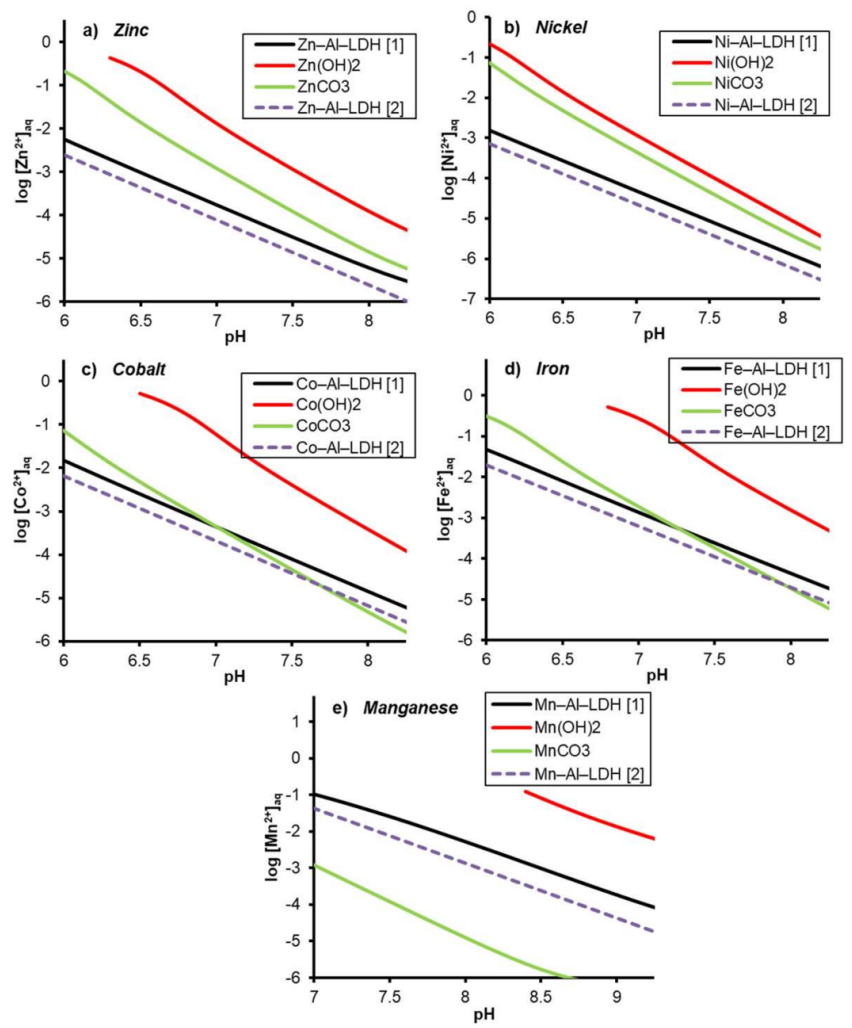

Figure 4. Comparison of the solubilities of $\mathrm{Me}(\mathrm{II})-\mathrm{Al}-\mathrm{LDH}, \beta-\mathrm{Me}(\mathrm{OH})_{2}$, and $\mathrm{MeCO}_{3}$ at circumneutral to alkaline $\mathrm{pH}$. Calculations were performed for $0.01 \mathrm{M} \mathrm{NaCl}$ electrolytes in equilibrium with atmospheric $P_{\mathrm{CO} 2}=10^{-3.5} \mathrm{~atm}$. Total aqueous $\mathrm{Me}(\mathrm{II})$ was dominated $(>80 \%)$ by freely dissolved $\mathrm{Me}^{2+}{ }_{(\mathrm{aq})}$ in all cases. The solid and dashed solubility lines of Me-Al-LDH were calculated using Equations (2) and (3), respectively.

Supplementary Materials: The following are available online at http://www.mdpi.com/2411-5126/2/2/20/s1: Figure S1: XRD patterns of hydrated $\gamma-\mathrm{Al}_{2} \mathrm{O}_{3}$ samples. Table S1: EXAFS data fitting results of $\mathrm{Me}(\mathrm{II})-\gamma \mathrm{Al}_{2} \mathrm{O}_{3}$ sorption samples and $\mathrm{Me}(\mathrm{II})-\mathrm{Al}(\mathrm{III})-\mathrm{LDH}$ references. Table S2: Summary of the solution chemical and thermodynamic data used to calculate $\mathrm{Ksp}$ of the $\mathrm{Me}(\mathrm{II})-\mathrm{Al}(\mathrm{III})-\mathrm{LDH}$ phases formed in the equilibrated sorption samples.

Acknowledgments: This work was supported by National Science Foundation grant EAR-1226581. We acknowledge Argonne National Laboratory for use of the Advanced Photon Source, a U.S. Department of Energy Office of Science User Facility operated for the DOE office of Science by Argonne National Laboratory under contract DE-AC02-06CH11357. We thank the beamline scientists at 12-BMB for assistance with XAS data collection. We further thank Tony Nikischer (Excalibur), Matt Siebecker (University of Delaware), and Wei Li (Nanjing Univeristy) for providing LDH reference material and XAS spectra.

Author Contributions: Lasita Bhattacharya and Evert J. Elzinga conceived and designed the experiments; Lasita Bhattacharya performed the experiments and analyzed the data; Lasita Bhattacharya and Evert J. Elzinga wrote the paper.

Conflicts of Interest: The authors declare no conflict of interest.

\section{References}

1. Sparks, D.L. Toxic metals in the environment: The role of surfaces. Elements 2005, 1, 193-197. [CrossRef]

2. Sparks, D.L. Environmental Soil Chemistry, 2nd ed.; Academic Press: San Diego, CA, USA, 2003.

3. McBride, M.B. Environmental Chemistry of Soils; Oxford University Press: New York, NY, USA, 1994.

4. Scheidegger, A.M.; Sparks, D.L. Kinetics of the formation and the dissolution of nickel surface precipitates on pyrophyllite. Chem. Geol. 1996, 132, 157-164. [CrossRef]

5. Scheidegger, A.M.; Lamble, G.M.; Sparks, D.L. Spectroscopic evidence for the formation of mixed-cation hydroxide phases upon metal sorption on clays and aluminum oxides. J. Colloid Interface Sci. 1996, 186, 118-128. [CrossRef] 
6. Scheidegger, A.M.; Strawn, D.G.; Lamble, G.M.; Sparks, D.L. The kinetics of mixed Ni-Al hydroxide formation on clay and aluminum oxide minerals: A time-resolved XAFS study. Geochim. Cosmochim. Acta 1998, 62, 2233-2245. [CrossRef]

7. Towle, S.N.; Bargar, J.R.; Brown, G.E.; Parks, G.A. Surface precipitation of Co.(II)(aq) on $\mathrm{Al}_{2} \mathrm{O}_{3}$. J. Colloid Interface Sci. 1997, 187, 62-82. [CrossRef] [PubMed]

8. Ford, R.G.; Sparks, D.L. The nature of Zn precipitates formed in the presence of pyrophyllite. Environ. Sci. Technol. 2000, 34, 2479-2483. [CrossRef]

9. Ford, R.G.; Scheinost, A.C.; Scheckel, K.G.; Sparks, D.L. The link between clay mineral weathering and the stabilization of Ni surface precipitates. Environ. Sci. Technol. 1999, 33, 3140-3144. [CrossRef]

10. Scheinost, A.C.; Ford, R.G.; Sparks, D.L. The role of Al in the formation of secondary Ni precipitates on pyrophyllite, gibbsite, talc, and amorphous silica: A DRS study. Geochim. Cosmochim. Acta 1993, 63, 3193-3203. [CrossRef]

11. Scheinost, A.C.; Sparks, D.L. Formation of layered single- and double-metal hydroxide precipitates at the mineral/water interface: A multiple-scattering XAFS analysis. J. Colloid Interface Sci. 2000, 223, 167-178. [CrossRef] [PubMed]

12. Thompson, H.A.; Parks, G.A.; Brown, G.E. Dynamic interactions of dissolution, surface adsorption, and precipitation in an aging cobalt(II)-clay-water system. Geochim. Cosmochim. Acta 1999, 63, 1767-1779. [CrossRef]

13. Elzinga, E.J.; Sparks, D.L. Nickel sorption mechanisms in a pyrophyllite-montmorillonite mixture. J. Colloid Interface Sci. 1999, 213, 506-512. [CrossRef] [PubMed]

14. Elzinga, E.J.; Sparks, D.L. Reaction condition effects on nickel sorption mechanisms in illite-water suspensions. Soil Sci. Soc. Am. J. 2001, 65, 94-101. [CrossRef]

15. Scheckel, K.G.; Scheinost, A.C.; Ford, R.G.; Sparks, D.L. Stability of layered Ni hydroxide surface precipitates-A dissolution kinetics study. Geochim. Cosmochim. Acta 2000, 64, 2727-2735. [CrossRef]

16. Scheckel, K.G.; Sparks, D.L. Kinetics of the formation and dissolution of Ni precipitates in a gibbsite/amorphous silica mixture. J. Colloid Interface Sci. 2000, 229, 222-229. [CrossRef] [PubMed]

17. Boyle-Wight, E.J.; Katz, L.E.; Hayes, K.F. Macroscopic studies of the effects of selenate and selenite on cobalt sorption to $\gamma-\mathrm{Al}_{2} \mathrm{O}_{3}$. Environ. Sci. Technol. 2002, 36, 1212-1218. [CrossRef] [PubMed]

18. Boyle-Wight, E.J.; Katz, L.E.; Hayes, K.F. Spectroscopic studies of the effects of selenate and selenite on cobalt sorption to $\gamma-\mathrm{Al}_{2} \mathrm{O}_{3}$. Environ. Sci. Technol. 2002, 36, 1219-1225. [CrossRef] [PubMed]

19. Charlet, L.; Manceau, A. Evidence for the neoformation of clays upon sorption of Co.(II) and Ni(II) on silicates. Geochim. Cosmochim. Acta 1994, 58, 2577-2582. [CrossRef]

20. Trainor, T.P.; Brown, G.E.; Parks, G.A. Adsorption and precipitation of aqueous Zn(II) on alumina powders. J. Colloid Interface Sci. 2000, 231, 359-372. [CrossRef] [PubMed]

21. Roberts, D.R.; Ford, R.G.; Sparks, D.L. Kinetics and mechanisms of Zn complexation on metal oxides using EXAFS spectroscopy. J. Colloid Interface Sci. 2003, 263, 364-376. [CrossRef]

22. Li, W.; Livi, K.J.T.; Xu, W.; Siebecker, M.G.; Wang, Y.; Phillips, B.L.; Spaks, D.L. Formation of crystalline Zn-Al layered double hydroxide precipitates on $\gamma$-alumina: The role of mineral dissolution. Environ. Sci. Technol. 2012, 46, 11670-11677. [CrossRef] [PubMed]

23. Eick, M.J.; Fendorf, S.E. Reaction sequence of nickel(II) with kaolinite: Mineral dissolution and surface complexation and precipitation. Soil Sci. Soc. Am. J. 1998, 62, 1257-1267. [CrossRef]

24. Siebecker, M.; Li, W.; Khalid, S.; Sparks, D.L. Real time Q-EXAFS spectroscopy measures rapid precipitate formation at the mineral-water interface. Nat. Commun. 2014, 5, 5003. [CrossRef] [PubMed]

25. Siebecker, M.; Li, W.; Sparks, D.L. The important role of layered double hydroxides in soil chemical processes and remediation: What we have learned over the past 20 years. In Advances in Agronomy; Sparks, D.L., Ed.; Academic Press: New York, NY, USA, 2007; Volume 147, p. 5003. [CrossRef]

26. Elzinga, E.J. Formation of layered Fe(II)-Al(III)-hydroxides during reaction of Fe(II) with aluminum oxide. Environ. Sci. Technol. 2012, 46, 4894-4901. [CrossRef] [PubMed]

27. Zhu, Y.; Elzinga, E.J. Formation of layered Fe(II)-hydroxides during Fe(II) sorption onto clay and metal-oxide substrates. Environ. Sci. Technol. 2014, 48, 4937-4945. [CrossRef] [PubMed]

28. Zhu, Y.; Elzinga, E.J. Macroscopic and spectroscopic assessment of the co-sorption of Fe(II) with As(III) and As(V) on Al-oxide. Environ. Sci. Technol. 2015, 49, 13369-13377. [CrossRef] [PubMed]

29. Starcher, A.N.; Elzinga, E.J.; Sparks, D.L. Formation of a mixed Fe(II)-Zn-Al layered hydroxide: Effects of Zn co-sorption on Fe(II) layered hydroxide formation and kinetics. Chem. Geol. 2017, 464, 46-56. [CrossRef] 
30. Starcher, A.N.; Li, W.; Kukkadapu, R.K.; Elzinga, E.J.; Sparks, D.L. Fe(II) sorption on pyrophyllite: Effect of structural Fe(III) (impurity) in pyrophyllite on nature of layered double hydroxide (LDH) secondary mineral formation. Chem. Geol. 2016, 439, 152-160. [CrossRef]

31. Elzinga, E.J.; Zhu, Y. Co-sorption of aqueous Fe(II) and $\mathrm{Mn}(\mathrm{II})$ in anoxic aluminum-oxide suspensions. In Proceedings of the 249th ACS National Meeting \& Exposition, Denver, CO, USA, 22-24 March 2015; Abstract GEOC-114.

32. Taylor, R.M. The rapid formation of crystalline double hydroxy salts and other compounds by controlled hydrolysis. Clay Miner. 1984, 19, 591-603. [CrossRef]

33. Evans, D.G.; Slade, R.C.T. Structural aspects of layered double hydroxides. Struct. Bond. 2006, 119, 1-87.

34. Bravo-Suarez, J.J.; Paez-Mozo, E.; Oyama, S.T. Review of the synthesis of layered double hydroxides: A thermodynamic approach. Quim. Nova 2004, 27, 60-614. [CrossRef]

35. Cavani, F.; Trifiro, F.; Vaccari, A. Hydrotalcite type anionic clays: Preparation, properties and applications. Catal. Today 1991, 11, 173-301. [CrossRef]

36. Roberts, D.R.; Scheidegger, A.M.; Sparks, D.L. Kinetics of mixed Ni-Al precipitate formation on a soil clay fraction. Environ. Sci. Technol. 1999, 33, 3749-3754. [CrossRef]

37. Juillot, F.; Morin, G.; Ildefonse, P.; Trainor, T.P.; Benedetti, M.; Galoisy, L.; Calas, G.; Brown, G.E. Occurrence of $\mathrm{Zn} / \mathrm{Al}$ hydrotalcite in smelter-impacted soils from Northern France: Evidence from EXAFS spectroscopy and chemical extractions. Am. Mineral. 2003, 88, 509-526. [CrossRef]

38. Voegelin, A.; Kretzschmar, R. Formation and dissolution of single and mixed Zn and Ni precipitates in soil: Evidence from column experiments and extended X-ray absorption fine structure spectroscopy. Environ. Sci. Technol. 2005, 39, 5311-5318. [CrossRef] [PubMed]

39. Voegelin, A.; Pfister, S.; Scheinost, A.C.; Marcus, M.A.; Kretzschmar, R. Changes in zinc speciation in field soil after contamination with zinc oxide. Environ. Sci. Technol. 2005, 39, 6616-6623. [CrossRef] [PubMed]

40. Peltier, E.; Allada, R.; Navrotsky, A.; Sparks, D.L. Nickel solubility and precipitation in soils: A thermodynamic study. Clays Clay Miner. 2006, 54, 153-164. [CrossRef]

41. Peltier, E.; Van Der Lelie, D.; Sparks, D.L. Formation and stability of Ni-Al hydroxide phases in soils. Environ. Sci. Technol. 2010, 44, 302-308. [CrossRef] [PubMed]

42. Jacquat, O.; Voegelin, A.; Villard, A.; Marcus, M.A.; Kretzschmar, R. Formation of Zn-rich phyllosilicate, Zn-layered double hydroxide and hydrozincite in contaminated calcareous soils. Geochim. Cosmochim. Acta 2008, 72, 5037-5054. [CrossRef]

43. Nachtegaal, M.; Marcus, M.A.; Sonke, J.E.; Vangronsveld, J.; Livi, K.J.T.; Van Der Lelie, D.; Sparks, D.L. Effects of in situ remediation on the speciation and bioavailability of zinc in a smelter contaminated soil. Geochim. Cosmochim. Acta 2005, 69, 4649-4664. [CrossRef]

44. McNear, D.H.; Chaney, R.L.; Sparks, D.L. The effects of soil type and chemical treatment on nickel speciation in refinery enriched soils: A multi-technique investigation. Geochim. Cosmochim. Acta 2007, 71, 2190-2208. [CrossRef]

45. Shi, Z.; Peltier, E.; Sparks, D.L. Kinetics of Ni sorption in soils: Roles of soil organic matter and Ni precipitation. Environ. Sci. Technol. 2012, 46, 2212-2219. [CrossRef] [PubMed]

46. Johnson, C.A.; Glasser, F.P. Hydrotalcite-like minerals $\left(\mathrm{M}_{2} \mathrm{Al}(\mathrm{OH})_{5}\left(\mathrm{CO}_{3}\right) 0.5 . \mathrm{H}_{2} \mathrm{O}\right.$, where $\mathrm{M}=\mathrm{Mg}, \mathrm{Zn}, \mathrm{Co}$., $\mathrm{Ni}$ in the environment: Synthesis, characterization and thermodynamic stability. Clays Clay Miner. 2003, 51, 1-8. [CrossRef]

47. Regelink, I.C.; Temminghoff, E.J.M. Ni adsorption and Ni-Al LDH precipitation in a sandy aquifer: An experimental and mechanistic modeling study. Environ. Pollut. 2011, 159, 716-721. [CrossRef] [PubMed]

48. Boclair, J.W.; Braterman, P.S. Layered double hydroxides. 1. Relative stabilities of layered double hydroxides and their simple counterparts. Chem. Mater. 1999, 11, 298-302. [CrossRef] [PubMed]

49. Allada, R.K.; Peltier, E.; Navrotsky, A.; Casey, W.H.; Johnson, C.A.; Berbeco, H.T.; Sparks, D.L. Calorimetric determination of the enthalpies of formation of hydrotalcite-like solids and their use in the geochemical modeling of metals in natural waters. Clays Clay Miner. 2006, 54, 409-417. [CrossRef]

50. Allada, R.K.; Navrotsky, A.; Berbeco, H.T.; Casey, W.H. Thermochemistry and aqueous solubilities of hydrotalcite-like solids. Science 2002, 296, 721-723. [CrossRef] [PubMed]

51. Carrier, X.; Marceau, E.; Lambert, J.F.; Che, M. Transformations of gamma-alumina in aqueous suspensions. 1. Alumina chemical weathering studies as a function of pH. J. Colloid Interface Sci. 2007, 308, 429-437.

52. Wijnja, H.; Schulthess, C.P. ATR-FTIR and DRIFT spectroscopy of carbonate species at the aged gamma-Al2O3/water interface. Spectrochim. Acta Part A 1999, 55, 861-872. 
53. Ressler, T. WinXAS: A new software package not only for the analysis of energy-dispersive XAS data. J. Phys. IV 1997, 7, C2-269. [CrossRef]

54. Ankudinov, A.L.; Rehr, J.J. Relativistic calculations of spin-dependent X-ray-absorption spectra. Phys. Rev. B 1997, 56, R1712-R1715. [CrossRef]

55. Ravel, B.; Newville, M. ATHENA, ARTEMIS, HEPHAESTUS: Data analysis for X-ray absorption spectroscopy using IFEFFIT. J. Synchrotron Radiat. 2005, 12, 537-541. [CrossRef] [PubMed]

56. Huminicki, D.M.C.; Hawthorne, F.C. The crystal structure of nikischerite, $\mathrm{NaFe}^{2+}{ }_{6} \mathrm{Al}_{3}\left(\mathrm{SO}_{4}\right)_{2}(\mathrm{OH})_{18}\left(\mathrm{H}_{2} \mathrm{O}\right)_{12}$ a mineral from the shigaite group. Can. Mineral. 2003, 41, 79-82. [CrossRef]

57. Gou, W.X.; Ji, J.F.; Li, W. An EXAFS investigation of the mechanism of competitive sorption between Co.(II) and $\mathrm{Ni}$ (II) at gamma-alumina/solution interface. Acta Geochim. 2017, 36, 462-464. [CrossRef]

58. Gustaffson, J.P. Visual MINTEQ Chemical Equilibrium Model Version 3.1; Stockholm Royal Institute of Technology (KTH): Stockholm, Sweden, 2017.

59. Shannon, R.D. Revised effective ionic radii and systematic studies of interatomic distances in halides and chalcogenides. Acta Cryst. 1976, A32, 751-767. [CrossRef]

60. Brown, T.; LeMay, H.E.; Bursten, B. Chemistry: The Central Science, 8th ed.; Prentice-Hall: Upper Saddle River, NJ, USA, 2002.

61. Borch, T.; Kretzschmar, R.; Kappler, A.; Van Cappellen, P.; Ginder-Vogel, M.; Voegelin, A.; Campbell, K. Biogeochemical redox processes and their impact on contaminant dynamics. Environ. Sci. Technol. 2010, 44, 15-23. [CrossRef] [PubMed]

62. Weber, K.A.; Achenbach, L.A.; Coates, J.D. Microorganisms pumping iron: Anaerobic microbial iron oxidation and reduction. Nat. Rev. Microbiol. 2006, 4, 752-764. [CrossRef] [PubMed]

63. Lovley, D.R.; Phillips, E.J.P. Organic matter mineralization with reduction of ferric iron in anaerobic sediments. Appl. Environ. Microbiol. 1986, 51, 683-689. [PubMed]

64. Baedecker, M.J.; Cozzarelli, I.M. The determination and fate of unstable constituents of contaminated groundwater. In Groundwater Contamination and Analysis at Hazardous Waste Sites; Lesage, S., Jackson, R.E., Eds.; Marcel Dekker, Inc.: New York, NY, USA, 1992; p. 425.

65. Kirk, G. The Biogeochemistry of Submerged Soils; John Wiley \& Sons, Ltd.: Chichester, UK, 2004.

66. Ponnamperuma, F.N. The chemistry of submerged soils. Adv. Agron. 1972, 24, $29-96$.

67. Hem, J.D. Study and Interpretation of the Chemical Characteristics of Natural Water, 3rd ed.; United States Government Printing Office: Washington, DC, USA, 1985.

68. Rashid, M.A.; Leonard, J.D. Modifications in the solubility and precipitation behavior of various metals as a result of their interaction with sedimentary humic acid. Chem. Geol. 1973, 11, 89-97. [CrossRef]

69. Fredrickson, J.K.; Gorby, Y.A. Environmental processes mediated by iron-reducing bacteria. Curr. Opin. Biotechnol. 1996, 7, 287-294. [CrossRef]

70. Burton, E.A.; Walter, L.M. The role of $\mathrm{pH}$ in phosphate inhibition of calcite and aragonite precipitation rates in seawater. Geochim. Cosmochim. Acta 1990, 54, 797-808. [CrossRef]

71. Sanchez-Roman, M.; Puente-Sanchez, F.; Parro, V.; Amils, R. Nucleation of Fe-rich phosphates and carbonates on microbial cells and exopolymeric substances. Front. Microbiol. 2015, 6, 1024. [CrossRef] [PubMed]

72. Nachtegaal, M.; Sparks, D.L. Nickel sequestration in a kaolinite-humic acid complex. Environ. Sci. Technol. 2003, 37, 529-534. [CrossRef] [PubMed]

73. Yamaguchi, N.U.; Scheinost, A.C.; Sparks, D.L. Influence of gibbsite surface area and citrate on Ni sorption mechanisms at pH 7.5. Clays Clay Miner. 2002, 50, 784-790. [CrossRef]

74. Yamaguchi, N.U.; Scheinost, A.C.; Sparks, D.L. Surface-induced nickel hydroxide precipitation in the presence of citrate and salicylate. Soil Sci. Soc. Am. J. 2001, 65, 729-736. [CrossRef]

75. Zhu, Y.; Liu, J.J.; Goswami, O.; Rouff, A.A.; Elzinga, E.J. Effects of humic substances on Fe(II) sorption onto aluminum oxide and clay. Geochem. Trans. 2018, 19, 3. [CrossRef] [PubMed]

(C) 2018 by the authors. Licensee MDPI, Basel, Switzerland. This article is an open access article distributed under the terms and conditions of the Creative Commons Attribution (CC BY) license (http:/ / creativecommons.org/licenses/by/4.0/). 